\title{
Multifunctional Equipment for Low-temperature Separation of Food Solutions Based on The Effect of "Thermal Paradox"
}

\author{
Burdo O.G. ${ }^{1}$, Terziev S. G. ${ }^{2}$, Mordynskiy V.P. ${ }^{1}$, Sirotyuk I.V. ${ }^{1}$, Fateeva Ya.A. ${ }^{1}$ \\ ${ }^{1}$ Odessa National Academy of Food Technologies, Odessa, Ukraine \\ ${ }^{2}$ PRJSC “ENNI FOODS”, Odessa, Ukraine
}

\begin{abstract}
The analysis of studies devoted to food solutions separation was carried out. The evolution of cryoconcentration technologies is analyzed, including the research works of the authors in the field of the block freezing plants. The purpose of the work is to reduce energy costs in block freezing plants and to intensify the process of the ice block formation. A hypothesis states that energy efficiency can be improved by recycling ice, using its energy to supercool the refrigerant before throttling. To intensify heat and mass transfer during crystallization, a scientific and technical idea for the implementation of the "thermal paradox effect" is proposed. The essence of the effect is that, with a certain combination of design and operating parameters of a block freezer, the growth of an ice block leads to a decrease in the total thermal resistance in the circuit "refrigerant - block freezer's wall - ice block solution". The most significant result of the work was that it proved the possibility to harmonize the design and operating parameters and organized the process of separation the solutions into ice and concentrate while minimizing systemic cold losses, and, and thus the ways were proposed for developing the freezing concentration technique. The scientific significance of the obtained results lies in the fact that a new principle of efficient use of the ice block energy was proved in the work, and a new effect was obtained, which it was referred to by the authors as the "thermal paradox". The practical significance of the work was that a multifunctional freezing unit with ice recycling and frequency control of the compressor drive was created.
\end{abstract}

Keywords: heat and mass transfer, evaporation technologies, solution concentrating by freezing, seawater desalination, energy efficiency, modeling.

DOI: https://doi.org/10.52254/1857-0070.2022.1-53.04

UDC: 628.165-027.236:66.045.5-967:66.021.3/.4

\section{Echipament multifuncțional pentru separarea la temperaturi joase a soluțiilor alimentare pe baza efectului "paradoxului termic" \\ Burdo O.G. ${ }^{1}$, Terziev S.G. ${ }^{2}$, Mordânskâi V.P. ${ }^{1}$, Sirotiuc I.V. ${ }^{1}$, Fateeva Ia.A. ${ }^{1}$ \\ ${ }^{1}$ Acedemia Națională de tehnologii Alimentare din Odesa, Odesa, Ucraina \\ ${ }^{2}$ SAP "ENNI FOODS", Odesa, Ucraina}

Rezumat. Obiectivul lucrării este de a reduce consumul de energie în aparatele de congelare-bloc şi de a intensifica procesul de formare a blocurilor de gheaţă. S-a formulat ipoteza conform căreia eficiența energetică poate fi îmbunătățită prin reciclarea gheții, utilizând energia acesteia pentru a suprarăci agentul de răcire înainte de strangulare. Pentru intensificarea transferului de căldură și de masă în timpul cristalizării, se propune ideea științifică și tehnică de realizare a "efectului de paradox termic". Esența efectului constă în faptul că, în condițiile unei anumite combinații de parametri de proiectare și de regim ai unui congelator de blocuri, creșterea unui bloc de gheață duce la o reducere a rezistenței termice totale în lanţul "agent frigorific - perete de cristalizare - bloc de gheață - soluție". Rezultatul cel mai important al acestei lucrări este dovada posibilității de a ajusta parametrii de proiectare și de regim și de a organiza procesul de separare a soluțiilor în gheață și concentrat la minimizarea pierderilor sistemice de frig, și că au fost sugerate modalități de dezvoltare a tehnicii de concentrare prin congelare. Semnificația științifică a rezultatelor obținute constă în faptul că lucrarea dovedește un nou principiu de utilizare eficientă a energiei blocului de gheață și se obține un nou efect, pe care autorii 1-au numit "paradox termic". Semnificația lucrării constă în faptul că a fost propusă o bază teoretică pentru separarea soluțiilor la temperaturi scăzute, pe baza căreia a fost creată o instalație multifuncțională și eficientă din punct de vedere energetic. Sunt prezentate rezultatele testărilor caracteristicilor apei topite din Marea Neagră, prin utilizarea instalației de congelare.

Cuvinte-cheie: transfer de căldură şi masă, tehnologii de evaporare, soluţii de concentrare prin îngheț, desalinizarea apei de mare, eficiență energetică, modelare.

СБурдо О.Г., Терзиев С.Г.,

Мордынский В.П., Сиротюк И.В.,

Фатеева Я.А. 
Многофункциональное оборудование для низкотемпературного разделения пищевых растворов на основе эффекта «термического парадокса»

Бурдо О.Г. ${ }^{1}$, Терзиев С.Г. ${ }^{2}$, Мордынский В.П. ${ }^{1}$, Сиротюк И.В. ${ }^{1}$, Фатеева Я.А. ${ }^{1}$

${ }^{1}$ Одесская национальная академия пищевых технологий, Одесса, Украина

2 ЧАО «Енни Фудз», Одесса, Украина

Аннотация. Проведен анализ исследований в направлении разделения пищевых растворов. Выполнено сравнение энергетики традиционных вакуум-выпарных аппаратов и криоконцентраторов. Анализируется эволюция технологий криоконцентрирования, в том числе и разработок авторов - установок блочного вымораживания. Определена цель работы - снижение затрат энергии в аппаратах блочного вымораживания и интенсификация процесса формирования блока льда. Сформулирована гипотеза, что энергетическая эффективность может быть повышена путем рециклинга льда, использование его энергии для переохлаждения холодильного агента перед дросселированием. Для интенсификации тепломассопереноса при кристаллизации предложена научно-техническая идея реализации «эффекта термического парадокса». Суть эффекта в том, что при определенном сочетании конструктивных и режимных параметров блочного вымораживателя рост блока льда приводит к снижению суммарного термического сопротивления в цепи «холодильный агент - стенка кристаллизатора — блок льда раствор». Установлено значение числа Био, при котором эффект максимален. Представлены результаты комплексных экспериментальных исследований, направленных на оптимизацию режимов работы блочной вымораживающей установки с рециклингом льда. Наиболее существенным результатом работы является доказательство возможности согласования конструктивных и режимных параметров и организовать процесс разделения растворов на лед и концентрат при минимизации системных потерь холода, и что предложены пути развития техники концентрирования вымораживанием. Научная значимость полученных результатов в том, что в работе доказан новый принцип эффективного использования энергии блока льда и получен новый эффект, который авторы назвали «термический парадокс». Значимость работы состоит в том, что предложены теоретические основы низкотемпературного разделения растворов, на основе которой создана энергоэффективная, многофункциональная установка. Установлено, что затраты энергии снижаются на 25\%. Установка эффективна как для концентрирования жидкостей, так и для деминерализации воды и генерации льда. Даны результаты проверки характеристик талой воды, полученной в вымораживающей установке из воды Черного моря.

Ключевые слова: тепломассообмен, технологии выпаривания, концентрирование растворов вымораживанием, опреснение морской воды, энергоэффективность, моделирование.

\section{ВВЕДЕНИЕ}

Оборудование для разделения растворов получило широкое распространение в промышленности. Целью разделительных процессов являются как удаление воды (получение концентратов), так и отделение солей (водоподготовка). Производство концентрированных продуктов динамично развивается во всем мире. Удаление части воды из продукта позволяет уменьшить объем жидкости для хранения и снизить стоимость транспортировки, уменьшить нежелательные химические, биохимические реакции и микробиологические процессы. В южных регионах Европы, которые специализируются, в основном, на выращивании и переработке овощей и фруктов, актуальна проблема получения высококачественных концентратов. Путем концентрирования, содержание растворимых сухих веществ, например, в соках можно повысить до $60-70 \%$ и, соответственно, уменьшить их объем, по сравнению с натуральным продуктом, в 5-6 раз. Наряду с этим, динамично растет необходимость в высококачественной воде.

Одной из главных проблем XXI является нехватка пресной воды, и до домов $46 \%$ жителей Земли вообще не подведен водопровод. Потребление пресной воды стремительно выросло и продолжает расти на $1 \%$ в год. 100 лет назад потребление пресной воды было в 6 раз меньше. Потребление воды в процентном соотношении в мире распределяется так: $12 \%$ - на домохозяйство, $19 \%$ - на промышленность и около $70 \%$ на сельское хозяйство [1].

\section{АНАЛИЗ ЛИТЕРАТУРНЫХ ИСТОЧНИКОВ, ФОРМУЛИРОВКА ПРОБЛЕМЫ И ГИПОТЕЗ}

Физический водный стресс уже является проблемой для многих регионов, включая Центральную Азию, Южную Азию, Северный Китай и Монголию, Анды и Андское побережье, Ближний Восток, 
Северную и Южную Африку, Мексику, Западную Америку.

Ожидается, что будущий рост потребности в воде будет наиболее острым в Бразилии, Индии, Индонезии и Китае, а также в других крупных странах, экономика которых и/или население быстро растет [2].

Наиболее распространённые методы водоподготовки это: дистилляция, обратный осмос и электродиализ.

Дистилляционные методы опреснения морской воды, многоступенчатый метод дистилляции, описанный автором [3], представляет собой многоступенчатую выпарную установку. Количество дистиллята, произведенного на установке с $\mathrm{N}$ ступенями, представляет собой сумму дистиллятов отдельных ступеней.

Следующий тип установки многоступенчатый метод дистилляции, описанный автором [3], называется «параллельный поток подачи». Здесь характерной особенностью является то, что каждая ступень состоит из горизонтального пучка теплообменных труб. Греющий пар добавляется в 1-ю ступень из котла, а конденсат из 1-й ступени снова направляется в котел. Это называется «параллельным потоком питательной среды», поскольку питательная вода распределяется равномерно параллельно всем элементам.

В работе [4] описаны методы опреснения морской воды: мембранные процессы, электродиализ, мембранная дистилляция, прямой осмос.

Метод опреснения обратным осмосом представляет собой процесс, который управляется давлением, при котором жидкость проходит через мембрану с помощью насоса. Наряду с преимуществами данного метода существуют и ряд недостатков. Для долгой службы мембраны необходима частая очистка или необходима соответствующая предварительная обработка сырья.

В работе [5] приведен анализ прибыли мирового рынка опреснения воды по технологиям (обратный осмос, многоступенчатая дистилляция и многоступенчатая фильтрация) за 20142025 года. Анализ показал, что такая технология как обратный осмос и другие методы фильтрации на основе мембран, займут лидерские позиции на мировом рынке опреснения благодаря меньшему потреблению энергии. Также показано, что альтернативным источником получения пресной воды будут на 1 месте морская вода, на 2 месте солоноватая и на 3 - сточные воды.

В пищевой отрасли, для сохранения полезных свойств продукта, много исследователей в своих работах используют метод вымораживания. Инновационный способ вымораживания был предложен авторами и защищен патентом (Бурдо О.Г. $и$ др., патент Украины № UA 35222). Авторы дали способу название «блочное вымораживание». Именно в этом названии заключена основная научно-техническая идея способа: осуществить процесс формирования блока льда на стадии кристаллизации, а не на стадии сепарирования, как это происходит в традиционных схемах. В настоящее время такой способ широко исследуется в мире. В работах [6-9] представлен метод блочного вымораживания для концентрации соков, чая, вина и т.д., также данный метод используется для концентрации молочной сыворотки [10, $11]$.

В сравнительной характеристике метода вымораживания и других методов концентрации пищевых растворов, описываемый метод дает лучшие показатели по сохранению качеств исходного продукта. Так в публикации [12] автор показывает, что сок, полученный в установке блочного вымораживания, имел лучшие показатели кислотности, цвета, витаминов, сахара, чем сок, полученный с использованием термического концентрирования.

Энергетические вопросы вымораживания рассмотрены в работе [13].

Аппарат для опреснения морской воды [14] сочетает в себе гидравлическую систему, тройную систему фильтрации и систему обратного осмоса. Проблема данной технологии состоит в том, что устройство довольно дорогостоящее и энергоемкое.

Морская вода по своему составу богата различными микроэлементами. Исследования морской воды разносторонние. Так, в работах $[15,16]$ разработан способ обеззараживания морской воды. Автор [17] описывает применение ультрафильтрации для получения высококачественной воды без определенных бактерий и вирусов, которые приводят к смертности устриц на фермах. Работа [16] описывает применение двух отдельных процессов: фотокатализа и 
озонирования, для обеззараживания загрязненной морской воды. Данные процессы применяются и для очистки сточных вод.

В публикации [18] представлено применение солнечной тепловой опреснительной установки, которая состоит из: солнечного коллектора, конденсационной камеры и угольного фильтра для опреснения морской воды.
Одним из способов получения пресной воды из морской является электролиз [19]. Растет интерес к технике блочного вымораживания для опреснения морской воды [20].

Техника разделения основана на использовании разных движущих сил. В мембранных технологиях - механические, при выпаривании - тепловые, а при вымораживании - диффузионные (табл. 1).

Сравнение методов разделения ${ }^{2}$

\begin{tabular}{|c|c|c|}
\hline $\begin{array}{l}\text { Метод / } \\
\text { Method }\end{array}$ & Достоинства / Advantages & Недостатки / Disadvantages \\
\hline $\begin{array}{l}\text { Выпаривания } \\
\text { / Evaporation }\end{array}$ & $\begin{array}{l}\text { Возможность тоннажного производства. } \\
\text { / Possibility of tonnage production. }\end{array}$ & $\begin{array}{l}\text { Проблемы переработки } \\
\text { термолабильного сырья. } \\
\text { / Problems with thermolabile raw material } \\
\text { processing. }\end{array}$ \\
\hline $\begin{array}{l}\text { Мембранный } \\
\text { / Membrane }\end{array}$ & $\begin{array}{l}\text { Высокое качество продукта. Низкие } \\
\text { затраты энергии. } \\
\text { / High quality of product. Low energy } \\
\text { consumption. }\end{array}$ & $\begin{array}{l}\text { Ограничение в конечной концентрации. } \\
\text { Проблемы при производстве мембран. } \\
\text { / Final concentration limitation. Problems } \\
\text { with membrane production. }\end{array}$ \\
\hline $\begin{array}{l}\text { Вымораживания } \\
\text { / Freezing }\end{array}$ & $\begin{array}{l}\text { Полное сохранение пищевой ценности } \\
\text { сырья. } \\
\text { / Full preservation of the raw material } \\
\text { nutrition value. }\end{array}$ & $\begin{array}{l}\text { Ограничение в конечной концентрации. } \\
\text { Значительные системные потери холода. } \\
\text { / Final concentration limitation. Significant } \\
\text { system cold losses. }\end{array}$ \\
\hline
\end{tabular}

Наибольшее распространение получили выпарные установки. Они отличаются относительной простотой конструкции и эксплуатации, большой производительностью. К недостаткам выпарных аппаратов относятся: значительные энергетические затраты (необходимые для перевода влаги в пар), ограниченное значение конечной концентрации и опасность порчи термолабильных компонентов сырья. Мембранные аппараты характеризуются минимальными энергетическими затратами на процесс так как протекают без фазового перехода. Вымораживающие установки реализуют диффузионные процессы. Криоконцентраторы характеризуются низкими затратами энергии и полным сохранением функциональных свойств компонентов. Однако оборудование требует высоких капитальных затрат, имеет ограниченное значение конечной концентрации. Кроме того, технологии вымораживания пока не глубоко исследованы.

Важным показателем эффективности разделительных установок являются удельные затраты энергии на удаление 1кг воды.
Физическая энергия, необходимая для превращения 1 кг воды в лед составляет 0,33 МДж, а при превращении воды в пар 2,6 МДж.

Несмотря на то, что стоимость производства холода примерно в два раза выше стоимости производства теплоты, расходы на осуществление фазового перехода при выпаривании выше, так как удельная теплота парообразования в 7 раз выше теплоты кристаллизации.

Кроме того, потери в окружающую среду при выпаривании выше из-за большего температурного градиента.

Пап [21] сравнил стоимость концентрирования выпариванием, вымораживанием и концентрирование обратным осмосом при различных производительностях установок и показал экономичность криоконцентрирования.

\section{ЭВОЛЮЦИЯ ТЕХНОЛОГИЙ ВЫМОРАЖИВАНИЯ ИЗ РАСТВОРОВ}

По сравнению с выпарными аппаратами история развития вымораживающих установок менее продолжительна. Однако наблюдаются определенные тенденции их 
совершенствования. Важным вопросом при функционировании технологии являются потери продукта со льдом. Представляется, что справедлива гипотеза авторов о зависимости величины общей поверхности льда от количества потерь продукта. Чем меньше эта поверхность, тем меньше продукта на ней находится, тем меньше продукта извлекается из раствора. Этот факт усиливается еще тем, что именно на поверхности сосредотачивается самый концентрированный раствор. Исходя из таких предпосылок, авторы предложили провести теплофизическую классификацию технологий вымораживанием, в основе которой положить фактор формы:

$$
a=\frac{\text { площадь поверхности льда }}{\text { объем льда }}
$$

По фактору а исследованы известные технологии. Соответствующие оценки сведены в таблице 2. Исследованы традиционные технологии (№1-4) и технологии блочного вымораживания, предложенные авторами (№5).

Сравнение технологий вымораживания по фактору формы ледяной фракции ${ }^{4}$

Таблица $2^{3}$.

\begin{tabular}{|c|c|c|c|c|}
\hline № & & $\mathrm{F}, \mathrm{m}^{2}$ & $\mathrm{~V}, \mathrm{~m}^{3}$ & $\mathrm{a}, \mathrm{m}^{-1}$ \\
\hline 1 & Кристаллы / Crystals, $\varnothing=30 \mu \mathrm{m}$ & $2,8310^{-9}$ & $1,410^{-14}$ & $210^{5}$ \\
2 & Кристаллы / Crystals, $\varnothing=70 \mu \mathrm{m}$ & $1,5310^{-8}$ & $1,810^{-13}$ & $0,810^{5}$ \\
3 & Кристаллы / Crystals, $\varnothing=300 \mu \mathrm{m}$ & $2,8310^{-7}$ & $1,410^{-11}$ & $210^{4}$ \\
4 & Слой льда / Ice layer, $\delta=2,5 \mathrm{~mm}$ & 2 & 0,005 & 400 \\
5 & Блок льда / Ice block, $\varnothing=150 \mathrm{~mm}$ & & & 26,7 \\
\hline
\end{tabular}

Общий объем потребления энергии при концентрировании вымораживанием складывается из двух составляющих: потребление энергии для обеспечения работы кристаллизатора и прочего оборудования (мешалок, насосов, центрифуг, промывных колонн) (табл. 3).
Традиционное концентрирования оборудование для вымораживанием характеризуется значительными системными потерями холода, что приводит к повышению и общего потребления энергии (табл. 3).

Затраты энергии при криоконцентрировании (кВт*час/1000кг льда) ${ }^{6}$

\begin{tabular}{|c|c|c|c|c|c|}
\hline \multicolumn{2}{|c|}{ Кристаллизатор / Crystallizer } & \multicolumn{2}{c|}{$\begin{array}{c}\text { Вспомогательное } \\
\text { оборудование / Auxiliary } \\
\text { equipment }\end{array}$} & \multicolumn{2}{c|}{ Общие / Total } \\
\hline $\min$ & $\max$ & $\min$ & $\max$ & $\min$ & $\max$ \\
\hline 25 & 80 & 55 & 220 & 80 & 300 \\
\hline
\end{tabular}

Вывод из (табл. 2 и 3) можно сделать однозначный: снижение общих затрат энергии на процесс разделения жидкостей вымораживанием связано, в первую очередь, c уменьшением энергоемкости вспомогательных систем (мешалок, насосов, центрифуг, промывных колонн, промежуточных емкостей и пр.). А формирование блока льда на стадии кристаллизации упростит проблему отделения раствора от ледяной фракции. Это важно, поскольку известная техника сепарирования не обладает должной эффективностью. Процесс сепарирования наиболее трудоемкий малопроизводительный в технологии криоконцентрирования.

Выполненный анализ позволяет сделать следующие выводы:

1. Традиционные

технологии выпаривания практически исчерпали свой резерв энергетической эффективности, в то время как при криоконцентрировании этот резерв до настоящего времени продолжает сохраняться.

2. Очевидное достоинство криоконцентрирования - высокое качество продукта.

3. Усилия ученых разных стран направлены на совершенствование 
технологии. Тенденции поисков - снижение потерь массы продукта за счет управления процессом кристаллизации и совершенствования принципов и средств разделения маточного раствора и льда.

Проведем сравнение технологий блочного вымораживания при разделении растворов с наиболее энергетически эффективной 7ступенчатой вакуум-выпарной установкой, у которой значение удельных затрат энергии составляет 1,5 МДж на 1кг удаленной влаги.

Низкотемпературные технологии разделения пищевых жидкостей вымораживанием 1 поколения (KT1), которые получили распространение в Европе, выбрали все свои резервы к 1990г. Предложенные авторами аппараты блочного вымораживания относятся к криотехнологиям 2 поколения (KT2, КT3, KT4). Аппараты KT4 требуют в 5 раз меньших энергетических затрат чем у 7ступенчатых вакуум-выпарных установок.

Снижение уровня энергетических затрат при блочном вымораживании (табл. 4) достигается за счет:

- сокращения расхода холода из-за отсутствия циркуляционных контуров и механизмов;

- применения гравитационного сепарирования, что стало возможным при формировании блока льда на стадии кристаллизации, а не сепарирования;

- использования в холодильном цикле энергии плавления блоков льда.

Таблица 47.

Энергетические аспекты развития низкотемпературных технологий разделения растворов ${ }^{8}$
Использование теплоты плавления блоков льда в блочных криоконцентраторах позволяет снизить уровень энергопотребления до

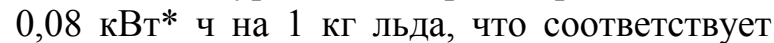
$\mathrm{J}=0,3$ МДж/кг. Это в 10 раз меньше, чем в одноступенчатых и в три раза меньше, чем в пятиступенчатых выпарных установках.

Непосредственно, кристаллизация происходит на стержневых поверхностях испарителях холодильной машины. Количество продукта, содержащегося в блоке льда, определяется соотношением скорости продвижения фронта кристаллизации и интенсивностью диффузии неводных компонентов из блока льда. Имеет место научно-техническое противоречие: чем выше производительность установки, тем хуже разделение воды и остальных компонентов. Параметром, который ответственен за указанное соотношение, является температура поверхности кристаллизатора. Чем она ниже, тем интенсивнее идет процесс льдообразования, но тем выше концентрация продукта в блоке льда. Чем выше 
температура кристаллизатора, тем ниже содержание продукта в блоке. Указанное противоречие решается оригинальным приемом - гравитационным сепарированием блока льда. Для сепарации блок льда выдерживается в камере, где под действием гравитационной силы происходит сток продукта из блока. Следует отметить, что чем ниже будет температура в камере, тем выше будет качество сепарации. Регулированием температуры в камере и продолжительности сепарирования можно достичь практически любого уровня содержания сухих веществ в блоке льда. Этап сепарации в этом методе происходит без дополнительных затрат энергии, под действием гравитационных сил.

Важные требования к конструкции кристаллизатора диктуются тепловой задачей. Формирование блока льда обязательно сопровождается ростом термического сопротивления блока. Поэтому, требуется системный анализ всех элементов теплопередачи, на основе которого конструкция кристаллизатора станет обоснованной.

В основе технологии научно-техническая гипотеза «термического парадокса».

\section{ГИПОТЕЗА \\ «ТЕРМИЧЕСКОГО ПАРАДОКСА»}

Суть гипотезы в том, что при определенном сочетании конструктивных и режимных параметров в процессе формирования блока льда общее термическое сопротивление системы «холодильный агент - лед - раствор» может снижаться.

Обозначим термические сопротивления элементов схемы: для холодильного агента $R_{X}$, для стенки трубы кристаллизатора $R_{C}$, блока льда $R_{L}$ и раствора $R_{P}$.

Тогда общее термическое сопротивление системы "холодильный агент - стенка — лед - раствор" будет равно их сумме:

$$
R=R_{X}+R_{C}+R_{L}+R_{P}
$$

Для кристаллизаторов цилиндрической формы соотношение (1) будет иметь вид:

$$
R=\frac{1}{\alpha_{X} d_{1}}+\frac{1}{2 \lambda_{C}} \ln \frac{d_{2}}{d_{1}}+\frac{1}{2 \lambda_{L}} \ln \frac{d_{L}}{d_{2}}+\frac{1}{\alpha_{P} d_{L}}
$$

При неизменных значениях коэффициентов теплоотдачи от холодильного агента к стенке $\left(\alpha_{X}\right)$ и от поверхности льда к раствору $\left(\alpha_{P}\right), \quad$ коэффициентов теплопроводности трубы $\left(\lambda_{C}\right)$ и льда $\left(\lambda_{L}\right)$, внутреннего $\left(d_{1}\right)$ и наружного $\left(d_{2}\right)$ диаметров трубы кристаллизатора общее термическое сопротивление системы становится функцией диаметра льда: $R=f\left(d_{L}\right)$. Причем, с ростом $d_{L}$ будет увеличиваться значение $R_{L}$, а величина $R_{P}$ будет снижаться. Объясняется это увеличением наружной поверхности теплообмена. Поэтому, характер $R$ будет определяться соотношением этих термических сопротивлений.

Исследование функции сводится к поиску экстремума. Для этого проведем дифференцирование функции и приравняем результат к нулю.

$$
\frac{d(R)}{d\left(d_{L}\right)}=\frac{1}{2 \lambda_{L} d_{L}}+\frac{1}{\alpha_{P} d_{L}}=0
$$

В экстремальной точке имеет место минимум общего термического сопротивления системы.

Минимум общего термического сопротивления характеризуется критическим значением диаметра льда $\left(d_{L C}\right)$. Именно это значение определяет диапазон целесообразных значений диаметров кристаллизаторов $\left(d_{2}\right)$.

Условие критического диаметра льда находится из соотношения:

$$
d_{L}=\frac{2 \lambda_{L}}{\alpha_{P}}
$$

Для предварительных оценок критический диаметр блока льда можно находить с помощью числа Био. Этот диаметр соответствует: $B i \approx 2 . \quad$ Естественно, наружный диаметр трубы кристаллизатора должен быть меньше значения критического диаметра блока льда.

Одной из особенностей процесса разделения методом блочного вымораживания является возможность внутренней рекуперации теплоты, которая аккумулируется в процессе льдообразования. Это становится возможным благодаря тому, что сам процесс кристаллизации необходим лишь для организации разделения, а не для получения холода в обычном понимании. Следовательно, блок льда является лишь побочным, а не основным продуктом разделения, благодаря чему энергию, которая аккумулируется в нем, можно вторично использовать. 


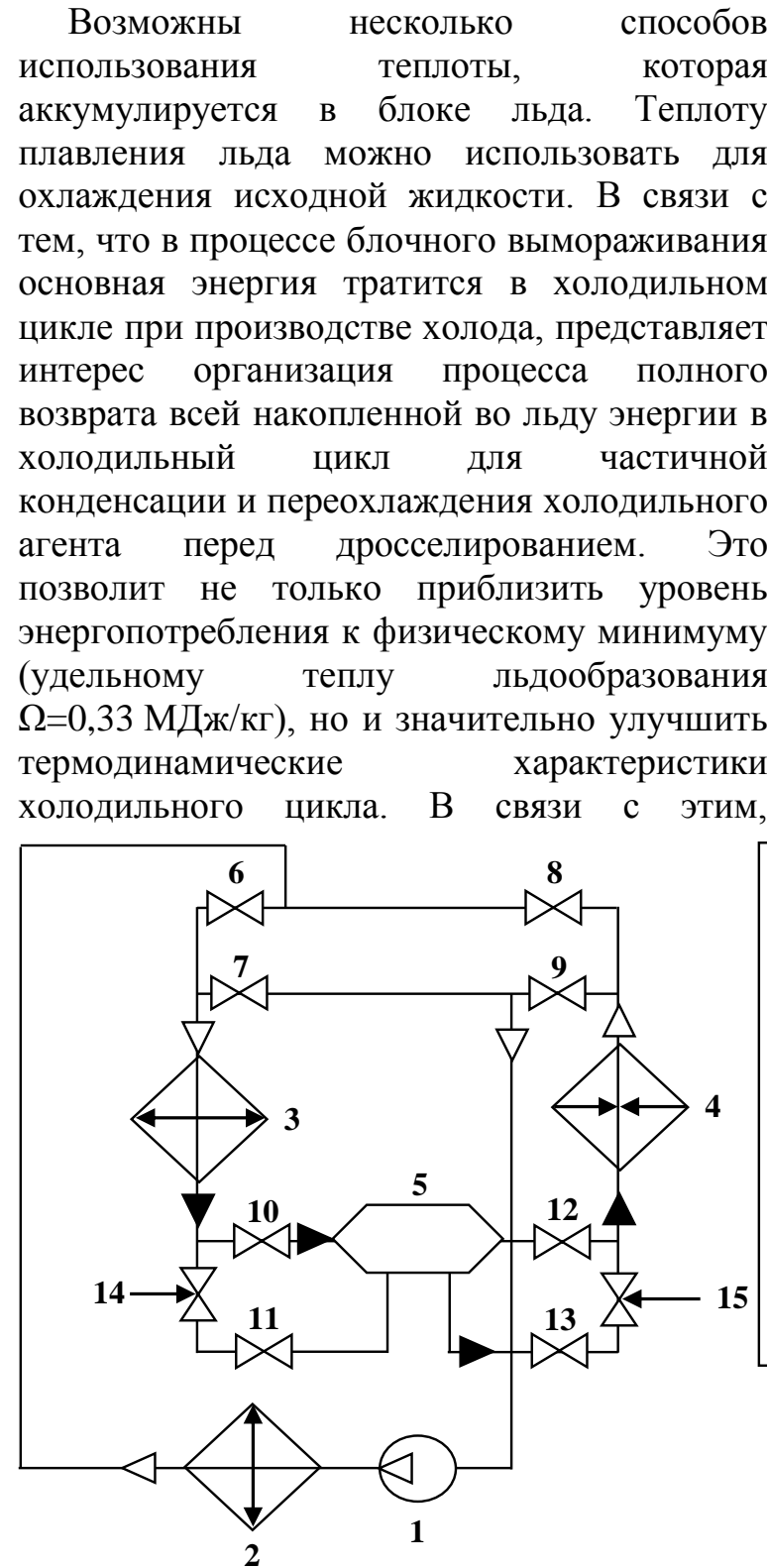

$1(\mathrm{Cm})$ - компрессор / compressor;

$2(C d)$ - конденсатор / condenser;

$3(\mathrm{Cr})$ - испаритель-кристаллизатор / evaporatorcrystallizer;

$4(M t)$ - плавитель / melter;

5 - линейный ресивер / line receiver.

$N_{l}$ - мощность компрессора / compressor power;

$Q_{1}$ - теплота конденсации / condensation heat;

$Q_{2}$ - теплота переохлаждения / subcooling heat;

$Q_{0}$ - холодопроизводительность / cooling capacity;

$G_{P}$ - расход раствора / solution flow;

$G_{W}-$ расход воды / water flow.

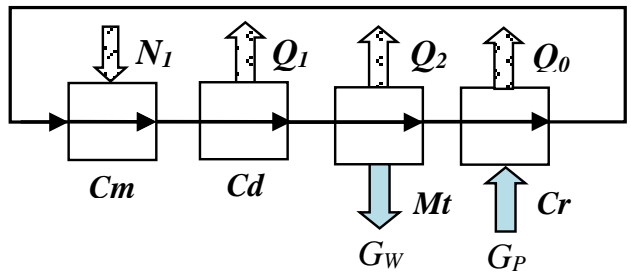

b)

а) принциииальная схема; b) схема потоков энергии и продукта

Рис. 1. Многофункциональная установка блочного вымораживания с рециклингом льда. 9

Первый закон термодинамики для установки (рис. 1б) запишется:

$$
N_{1}=Q_{1}-Q_{2}-Q_{0}
$$

Из (5) следует, что на первом цикле (запуске) установки $Q_{2}=0$.

При включении в работу плавителя мощность компрессора уменьшится. В самом плавителе энергия льда расходуется частично на нагрев льда $\left(Q_{H}\right)$ до температуры плавления и частично на плавление $\left(Q_{M T}\right)$. При этом, нагревается и изменяется агрегатное состояние блока льда:

$$
Q_{2}=Q_{H}+Q_{M T}=M_{L} c_{P L}\left(t_{M T}-t_{L}\right)+M_{L} \Omega
$$

В соотношении (6) принято: $M_{L}-$ массовый расход льда, $c_{P L}$ - удельная теплоемкость льда, $\Omega$ - удельная теплота плавления льда.

При установившемся режиме работа установки состоит из двух технологических циклов, которые последовательно 
изменяются. Эти циклы вымораживания и плавления осуществляются в теплообменниках 3 и 4 (рис. 1а). Допустим, что в $i$-ом цикле теплообменник 3 выполняет функцию вымораживателя, тогда теплообменник 4 является плавителем и в нем находится блок льда, намороженный в предыдущем цикле. При этом вентили 9, 6, $10,13,15$ открыты, а вентили 7, 8, 11, 12, 14 закрыты. Исходный раствор подается в теплообменник 4, где за счет теплоты кипения холодильного агента осуществляется концентрирование раствора и формирование блока льда.

Моделирование процесса формирования блока льда проведено при допущениях:

- тепломассоперенос осуществляется на поверхности в ограниченном пространстве между непроницаемыми стенками, кристаллизация в объеме отсутствует;

- процесс происходит в условиях естественной конвекции, которая вызвана температурным градиентом;

- все сухие вещества раствора рассматриваются как один компонент с известными теплофизическими свойствами;

- задача рассматривается для определенного отрезка времени, в котором действуют средние значения температур и концентраций;

- раствор в начальный момент времени находится при температуре фазового перехода;

- температура поверхности льда определяется криоскопическими условиями;

— изменение энтальпии твердой фазы незначительное по сравнению с теплотой кристаллизации.

Общее уравнение теплового баланса имеет вид:

$$
Q=c_{P} V_{P} \rho_{P} \frac{\theta t_{P}}{\theta \tau}+\Omega F_{L} \frac{d r_{L}}{\theta \tau}+Q_{L O S S}
$$

С учетом приведенных допущений для безразмерной координаты $x=\left(r_{L}-r_{E}\right) /\left(r_{C}-r_{E}\right)$ определяется

безразмерное время вымораживания:

$$
F_{0}=\frac{P h}{2(n+1)}\left(1+\frac{2}{B i_{T}}\right)
$$

Где $B i_{T}$ - число Био тепловое:

$$
B i=\alpha_{X} r_{T}\left(\frac{\frac{\ln r_{C}}{r_{T}}}{\lambda_{T}}+\frac{\frac{\ln r_{L}}{r_{C}}}{\lambda_{L}}\right)
$$

$P h$ - число фазового перехода [23]:

$$
P h=\frac{\rho_{P} \Omega}{\rho c_{P L}\left(t_{P}-t_{C}\right)}
$$

$n$ - константа, которая характеризует форму блока льда, для цилиндра $n=1 ; r_{T}-$ внутренний радиус стенки кристаллизатора, м; $r_{C}$ - радиус концентратора, м; $r_{L}-$ радиус блока льда, м; $\rho_{P}, \rho_{L}-$ плотность раствора и льда, кг $/ \mathrm{M}^{3} ; \Omega-$ удельная теплота кристаллизации, Дж/кг.

Приведенная модель хорошо отражает тепловое состояние системы, но не учитывает особенностей массопереноса на границе «лед - раствор» при концентрировании пищевых жидкостей, которые являются сложными многокомпонентными системами. Поэтому, для определения действительного времени кристаллизации необходимо ввести корректировочный коэффициент, который учел бы указанную специфику. С учетом изменения энтальпии твердой фазы и особенностей массопереноса на границе «лед - раствор» действительное время процесса составит:

$$
\tau=\tau_{0} \psi_{1} \psi_{2}
$$

где $\psi_{1}$ - коэффициент, который учитывает изменение энтальпии твердой фазы:

$$
\psi_{1} \approx 1+\frac{1}{2}\left(\frac{B i_{T}}{B i_{T}+1}\right)^{\frac{2}{3}}\left(\sqrt{1+2 \frac{\frac{F_{L} r_{L}}{V_{L}}}{P h}}-1\right)
$$

где $F-$ площадь поверхности блока льда, $\mathrm{m}^{2} ; V_{L}$ - объем блока льда, $\mathrm{M}^{3}$.

В соотношении (11) $\psi_{2}$ - коэффициент, который учитывает специфику массообменных процессов при блочном вымораживании:

$$
\psi_{2}=A\left(B i_{D}\right)^{k}
$$

$B i_{D}$ - число Био диффузионное:

$$
B i_{D}=\frac{\beta r_{L} \ln \left(r_{L} / r_{C}\right)}{D}
$$


где $\beta-$ коэффициент интенсивности массопереноса от раствора к блоку льда, м/с;

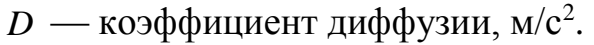

В работе эти коэффициенты установлены экспериментально.

\section{ОПТИМИЗАЦИЯ \\ ВЫМОРАЖИВАЮЩЕЙ УСТАНОВКИ С РЕЦИКЛИНГОМ ЛЬДА}

Исследована пилотная установка производительностью 10 кг льда в час и общей емкостью концентратора 30 л.

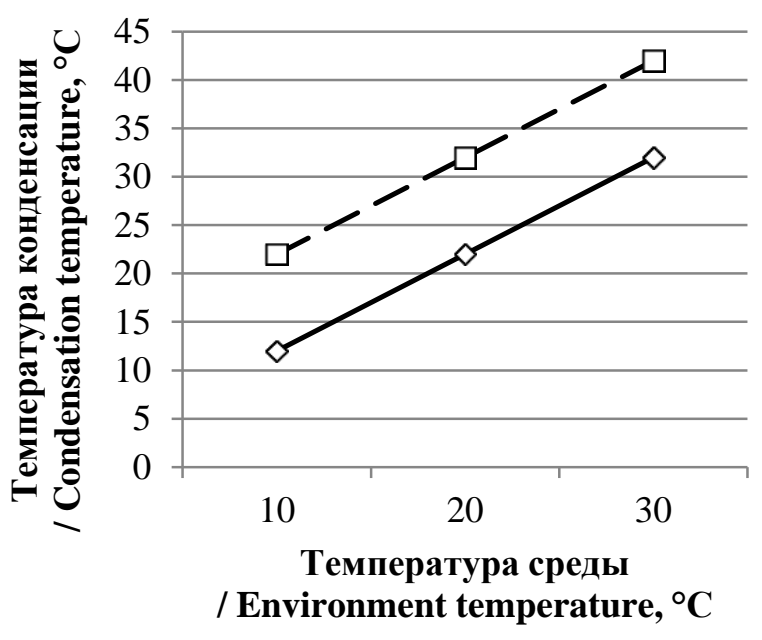

a)
Установка состоит из 3-х основных элементов, смонтированных на металлическом каркасе: компрессорноконденсаторного агрегата, блока кристаллизаторов-плавителей и блока управления (рис. 1).

При проведении экспериментальных исследований регистрировались расходы электроэнергии, температуры в узловых точках цикла холодной машины, параметры блока льда и раствора.

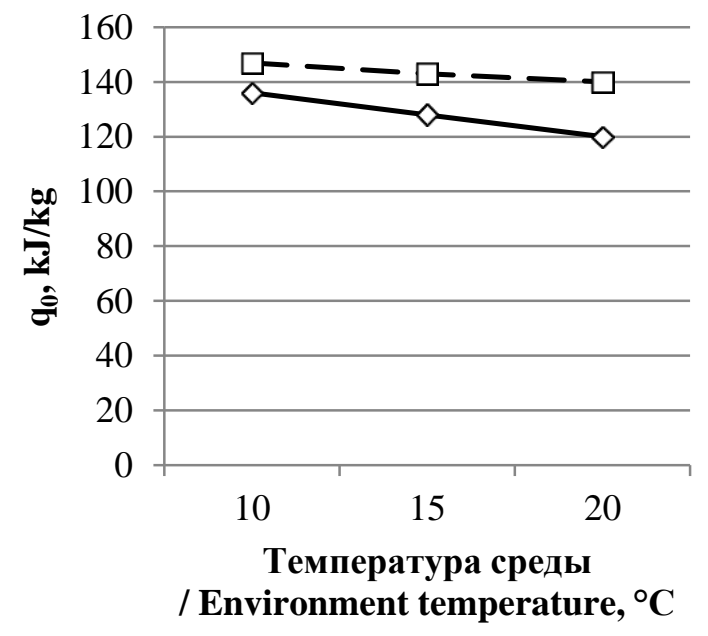

б)

Рис. 2. Зависимость параметров холодильного цикла от температуры окружающей среды. ${ }^{11}$

Верхние линии (рис. 2а) соответствуют традиционному циклу, а нижние - циклу с рециклингом льда. Установлено, что при осуществлении рециклинга льда температура конденсации снижается на $(9.20)^{\circ} \mathrm{C}$ (рис. 2a) по сравнению с базовым циклом, а удельная холодопроизводительность

на $(10 . .25) \%$ (рис. 2б). Затраты электроэнергии на процесс блочного вымораживания в схеме с рециклингом льда сокращаются в 1,2...1,4 раза.

Проведены эксперименты аппарата для водоочистки, который содержал змеевиковый кристаллизатор из труб диаметром 0,006 м, с общей длинной $\mathrm{h}=7$ м. Сопоставление данных расчета по (11) с результатами экспериментов показало, что поправочный коэффициент $\psi=2,5$. Поэтому, $\tau=2,5 \tau_{\min }$.

Определены зависимости удельных энергозатрат от температуры кипения холодильного агента для различных начальных концентраций раствора. Анализ полученной серии кривых (рис. 3) показал, что для каждой начальной концентрации раствора существует свой ярко выраженный минимум.

При отклонении температуры кипения от минимума в сторону ее увеличения удельные энергозатраты резко увеличиваются, асимптотически приближаясь к бесконечности в точках, соответствующих криоскопическим условиям системы в начальный момент времени. Из рис. 3 видно, что при увеличении исходной концентрации раствора снижается значение целесообразной температуры кипения холодильного агента и растет соответствующее ему значение удельных энергозатрат. Кроме начальной концентрации раствора и температуры кипения холодильного агента, не менее важным параметром, влияющим на энергозатраты при криоконцентрировании, является время ведения процесса. 


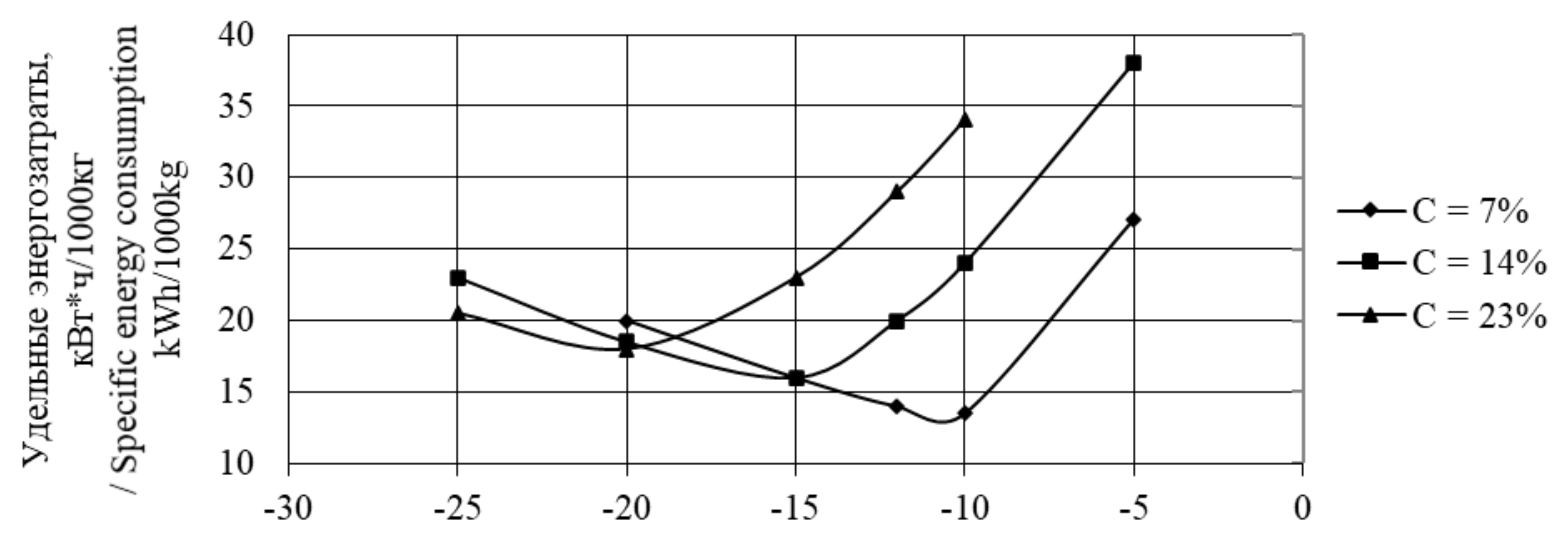

Температура кипения / Boiling temperature, ${ }^{\circ} \mathrm{C}$

Рис. 3. Зависимость удельных энергозатрат от температуры кипения холодильного агента для различных концентраций раствора. ${ }^{11}$

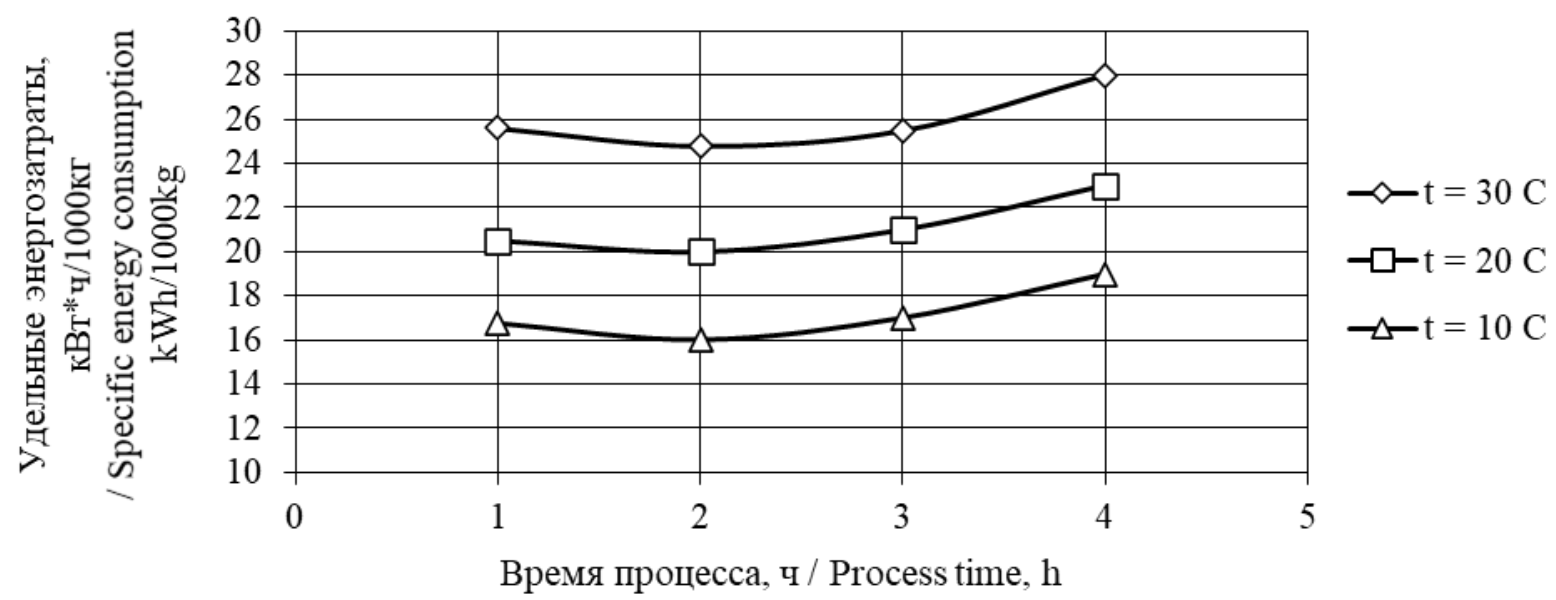

Рис. 4. Зависимость удельных затрат энергии от времени процесса для различных температур окружающей среды. ${ }^{12}$

Поскольку скорость роста блока льда во времени существенно меняется, а на затраты электроэнергии оказывают влияние параметры окружающей среды, то была проанализирована, также, для различных температур окружающей среды зависимость удельных энергозатрат от времени ведения процесса (рис. 4).

Полученные кривые показали, что для всех температур окружающей среды графики $J=f(\tau)$ имеют локальный минимум при значении $\tau=2$ ч. Причем, для $\tau$ больше двух часов $J$ растет быстрее, чем при $\tau$ меньше двух часов. Поскольку в области $0<\tau<2$ ч минимум имеет размытый характер, то рекомендуются значения $\tau=1,5-2$ ч.

Перспективные результаты получены при исследовании на установке процессов деминерализации воды Черного моря. В установку залили 10 л воды Черного моря с начальным значением солесодержания 18 г/л (табл. 5).

Таблица $5 .^{13}$

Результаты экспериментов по деминерализации воды Черного моря ${ }^{14}$

\begin{tabular}{|c|c|c|c|c|c|}
\hline № & $\begin{array}{c}\text { Время, } \\
\text { мин } \\
\text { / Time, } \\
\text { min }\end{array}$ & $\begin{array}{c}\text { Высота воды в } \\
\text { кристаллизаторе } \\
\text { / Water level in the } \\
\text { crystallizer }\end{array}$ & $\begin{array}{c}\text { Толщина } \\
\text { льда } \\
\text { / Ice } \\
\text { thickness }\end{array}$ & $\begin{array}{c}\text { Концентрация солей льда } \\
\text { / Salts concentration in ice }\end{array}$ & $\begin{array}{c}\text { Температура } \\
\text { / Temperature }\end{array}$ \\
\hline 1 & 0 & $16 \mathrm{~cm}$ & - & - & $9^{\circ} \mathrm{C}$ \\
\hline 2 & 30 & $14,2 \mathrm{~cm}$ & $0,7 \mathrm{~cm}$ & $453 \mathrm{mg} / \mathrm{l}$ & $0,5^{\circ} \mathrm{C}$ \\
\hline
\end{tabular}


Через 30 минут работы установки блок льда уже отвечал допустимым стандартам питьевой воды по общему содержанию солей (табл. 5).

Дальнейшее гравитационное сепарирование блока льда позволяло получить воду с общим содержанием солей 4 мг/л, что представляет интерес и для медицины, и для техники.

Принципиально, установки блочного вымораживания должны иметь более широкие перспективы, чем сложные системы криоконцентрирования (рис. 5).

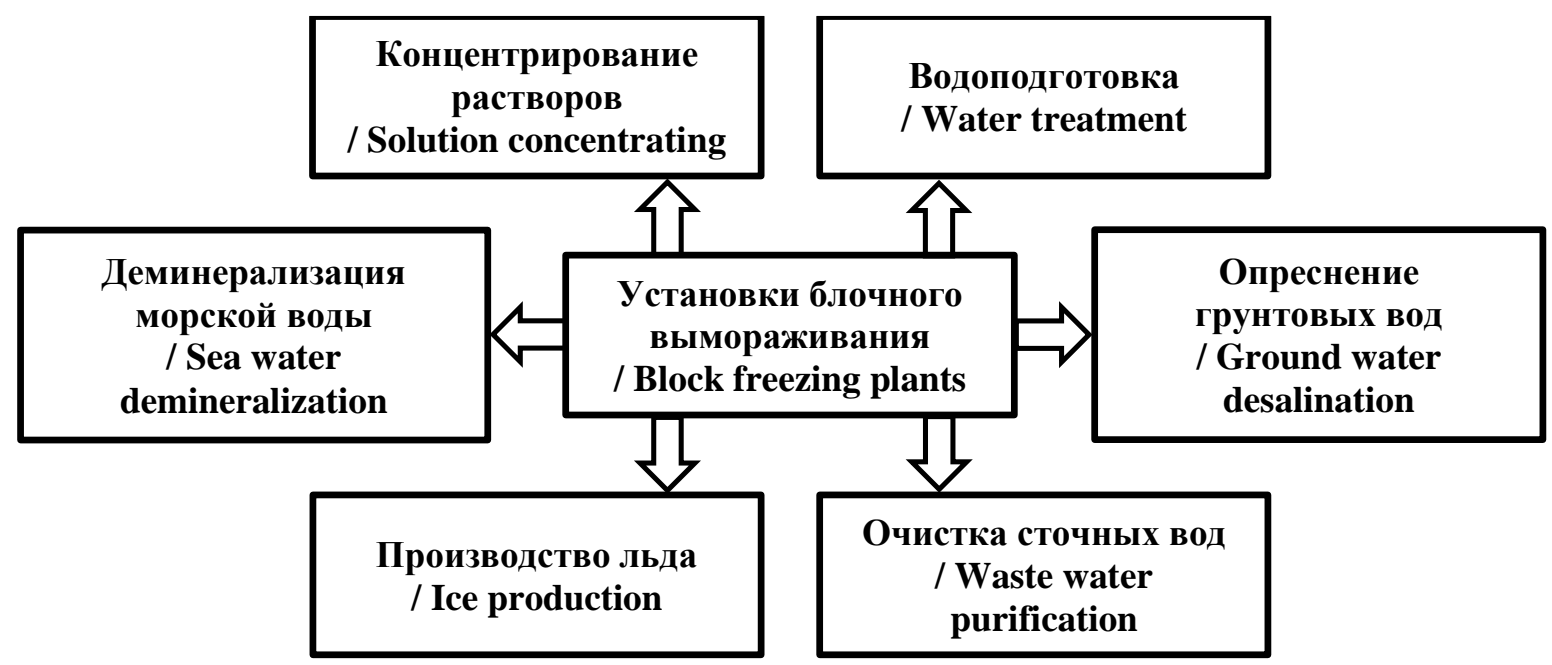

Рис. 5. Области применения технологий блочного вымораживания. ${ }^{15}$

Установки концентрирования, пищевых жидкостей блочного вымораживания предназначены для получения экологически чистых, максимально сохраняющих биоактивный комплекс сырья продуктов с минимальными энергетическими затратами: жидкие пищевые красители и ароматизаторы из отходов винодельческих и консервных производств; белковый концентрат из молочной сыворотки; концентрированное молоко; концентрированный виноматериал; концентрированная уксусная кислота; концентрированные соки, экстракты, талая биологически активная вода.

Установки блочного вымораживания для процессов водоподготовки: доочистка водопроводной питьевой воды; доочистка воды в пищевых технологиях; в теплоэнергетике, производство талой воды для производства водки, напитков и лечебно-профилактических экстрактов; опреснение грунтовых вод; опреснение вод морей и водоемов.

Установки блочного вымораживания эффективны как ледогенераторы, могут быть модернизированы для производства фигурного льда, цветного льда.

При очистке разнообразных жидких технологических стоков пищевых производств установки блочного вымораживания могут быть приспособлены для работы в условиях использования естественного холода.

Изготовлен пилотный образец многофункциональной блочной вымораживающей установки МБВ-1, производительность которой по льду составляет 1000 кг в сутки.

Сводка результатов расчета ключевого параметра (числа $P h$ ) по уравнению (10) представлена в таблице 6. Оценка проведена для трех уровней температур кипения в кристаллизаторе.

Получено, что для одинакового значения $\Delta X=25$ мм процесс кристаллизации длится 2,4 часа при $t_{X}=-8^{\circ} \mathrm{C}, 1,6$ часа при $t_{X}=-12^{\circ} \mathrm{C}$ и 1,025 часа при $t_{X}=-15^{\circ} \mathrm{C}$. Macca блока льда на одном кристаллизаторе составляла 1,1 кг.

Следующим шагом исследований являются выбор холодильного компрессора, анализ холодильного цикла и марки холодильного агента, a, также, способа регулирования холодильной мощности на технические и экономические характеристики установки.

${ }^{15}$ Appendix 1 
Основные результаты расчетов ${ }^{17}$

\begin{tabular}{|c|c|c|c|c|c|c|c|c|c|c|}
\hline & \multicolumn{4}{|c|}{$t_{X}=-8^{\circ} \mathrm{C}$} & \multicolumn{3}{|c|}{$t_{X}=-12^{\circ} \mathrm{C}$} & \multicolumn{3}{|c|}{$t_{X}=-15^{\circ} \mathrm{C}$} \\
\hline$P h$ & \multicolumn{4}{|c|}{22,159} & \multicolumn{3}{|c|}{14,772} & \multicolumn{3}{|c|}{11,818} \\
\hline$\tau, \mathrm{c}$ & 1384 & 3116 & 5540 & 8655 & 2077 & 3693 & 5770 & 1662 & 2980 & 4620 \\
\hline
\end{tabular}

Технико-экономический опреснителя блочного типа МБВ-1.

Теоретически необходимая холодильная мощность для функционирования $Z$ кристаллизаторов определяется из соотношения:

$$
Q=\frac{M_{L i} \Omega}{\tau_{i} 60} Z[\kappa B m]
$$

В соотношении $\Omega 333$ кДж/кг - удельная теплота льдообразования.
Число кристаллизаторов Z рассчитывается из условий необходимой общей производительности установки. Расчеты ведутся для трех моментов времени: 1 час, 2 часа и 3 часа.

Результаты расчетов для режима $t_{X}=-8^{\circ} \mathrm{C}$ приведены в таблице 7. Видно, что по мере роста массы льда в установке, значение необходимой для реализации процесса холодильной мощности снижается.

Аналогичные расчеты выполнены для всех анализируемых температурных режимов кристаллизатора.

Таблица $7 .{ }^{18}$

Расчетные значения параметров вымораживающей установки ${ }^{19}$

\begin{tabular}{|c|c|c|c|c|}
\hline & \multicolumn{4}{|c|}{ Режим / Mode $t_{X}=-8^{\circ} \mathrm{C}$} \\
\hline$\tau, \mathrm{h}$ & 1 & 1,5 & 2 & 3 \\
\hline $\mathrm{M}_{\mathrm{L}}, \mathrm{kg}$ & 434 & 651 & 868 & 1302 \\
\hline $\mathrm{Q}, \mathrm{W}$ & 40150 & 40045 & 39540 & 38145 \\
\hline
\end{tabular}

Компрессор подбирается по значению максимальной холодильной мощности. С помощью программного продукта
Coolselector2 [24] для исследуемых условий работы рекомендуются следующие модели компрессоров (табл. 8).

Таблица $8 .{ }^{20}$

Технические характеристики компрессоров ${ }^{21}$

\begin{tabular}{|c|c|c|c|c|c|c|}
\hline Model & $\mathbf{t}_{0},{ }^{\circ} \mathbf{C}$ & Technology & Voltage & $\begin{array}{c}\text { Cooling } \\
\text { capacity (W) }\end{array}$ & $\begin{array}{c}\text { Power } \\
\text { input (W) }\end{array}$ & $\begin{array}{c}\text { Mass Flow } \\
(\mathbf{k g} / \mathbf{h})\end{array}$ \\
\hline VTZ171-G & -8 & Reciprocating & $\begin{array}{c}400 / 57 \\
5 / 3\end{array}$ & 30112 & 8573 & 722 \\
\hline VTZ215-G & -12 & Reciprocating & $\begin{array}{c}400 / 57 \\
5 / 3\end{array}$ & 30109 & 9826 & 568 \\
\hline DSH295-4 & -15 & Scroll & $\begin{array}{c}400 / 57 \\
5 / 3\end{array}$ & 40510 & 10890 & 642 \\
\hline
\end{tabular}

После первого цикла подключается к работе плавитель льда, который дает возможность до $25 \%$ энергии возвращать в холодильный цикл. Соответственно, потребляемая электрическая мощность установки может быть снижена. Технически решать подобные задачи принято с помощью частотного преобразователя. Важно оценить срок окупаемости частотного преобразователя в новой для этого прибора

\section{области}

вымораживающей опреснительной установки с рециклингом льда. Расчет ведется для трехсменной работы установки, т.е. компрессор работает по 120 часов в неделю, 220 дней в году. Стоимость 1 кВт*часа электроэнергии в Европе варьируется в пределах 0,07-0,25 $€$.

Первые 3 часа потребляемая электрическая мощность составляет 10890 Вт. Затем, наступает второй цикл, 
подключается в работу плавитель льда и частотный преобразователь снизит потребление электрической мощности до 7740 Вт. Этот уровень потребления энергии

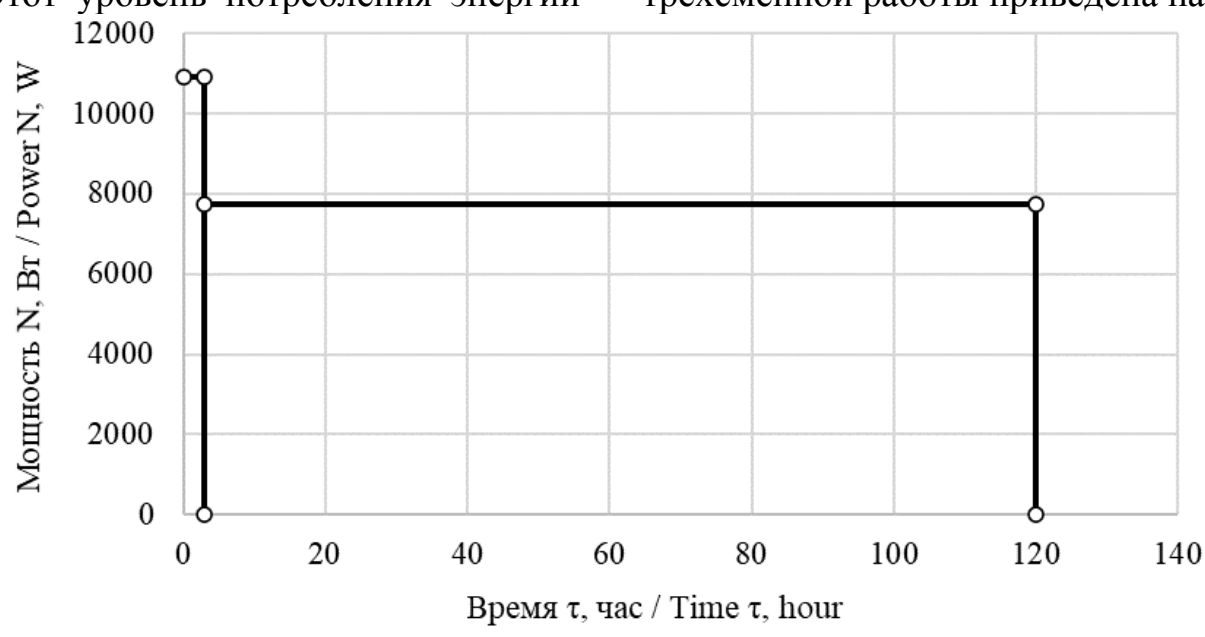

сохранится на протяжении остальных 117 часов.

Соответствующая циклограмма для трехсменной работы приведена на рисунке 6.

Рис. 6. Уровни потребления энергии компрессором. ${ }^{22}$

Проведем анализ для 2 схем. Базовая схема - без частотного преобразователя и предлагаемая схема — с частотным преобразователем. Предъявляемым требованиям отвечает частотный пре- образователь VLT HVAC, стоимость которого составляет $1380 €$.

Результаты расчета составляющих экономии энергии и материальных средств за год за счет работы частотного преобразователя представлены в таблице 9.

Таблица $9 .{ }^{23}$

Экономические показатели схем ${ }^{24}$

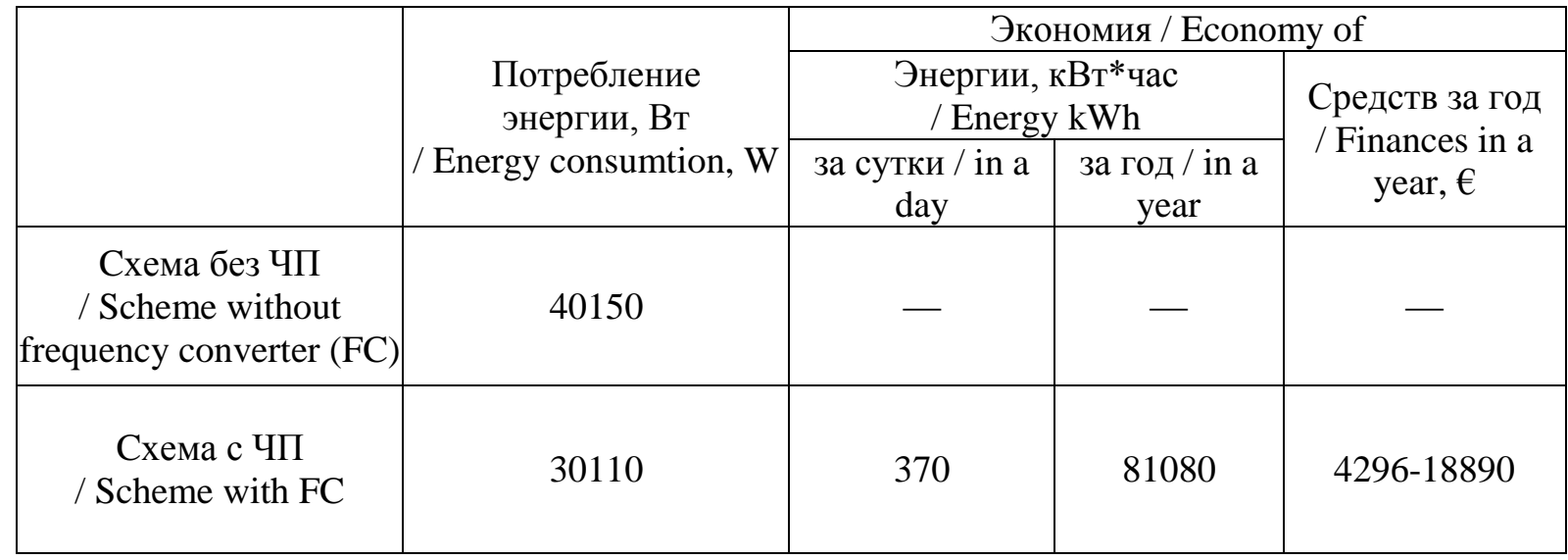

Сравнение экономических показателей двух схем и определение срока окупаемости частотного преобразователя проведено на рисунке 7.

Видно, что окупаемость частотного преобразователя в пределах 1 месяца при стоимости $1 \kappa \mathrm{BT}^{*}$ часа $0,25 €$ и 3 месяца при стоимости $1 \kappa \mathrm{BT}^{*}$ часа $0,07 €$. Энергетически целесообразный режим эксплуатации блочной опреснительной установки достигается при температурах на поверхности испарителя кристаллизатора $(-8 . . .-10)^{\circ} \mathrm{C}$.

Приведенная выше методика может быть использована при проектировании систем водоподготовки любой производительности. 


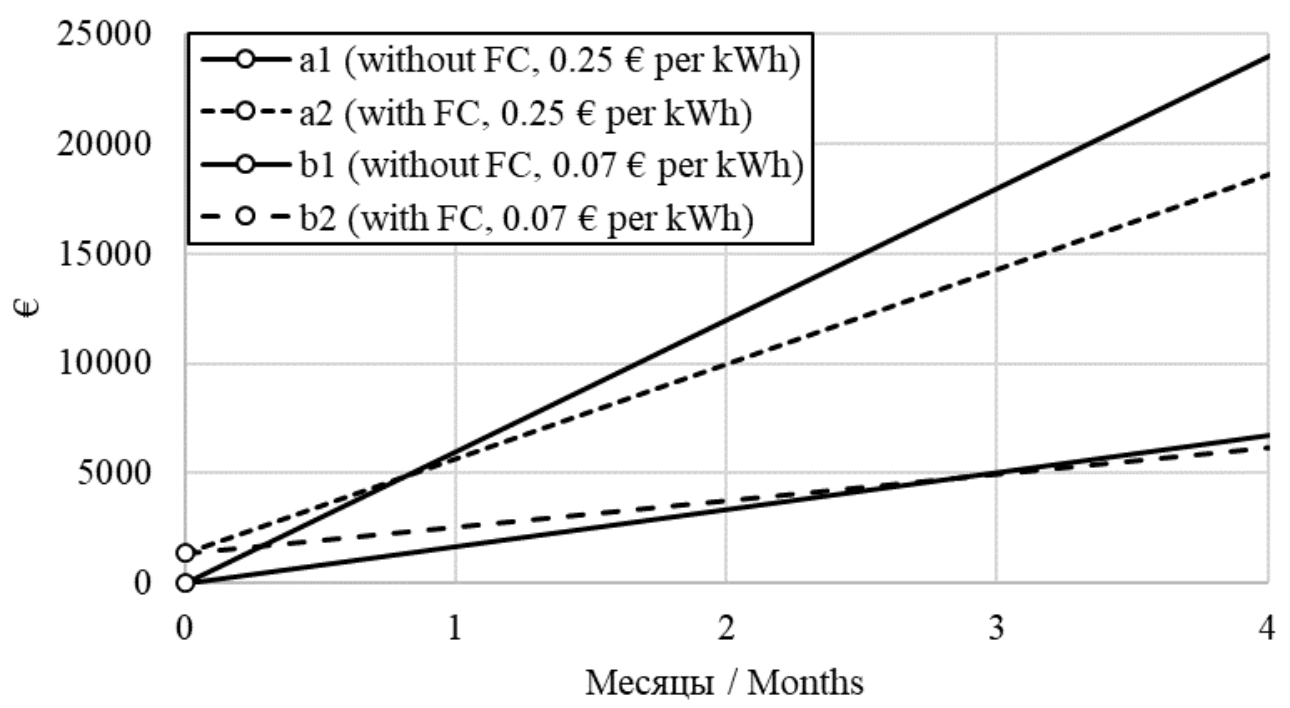

Рис. 7. Срок окупаемости частотного преобразователя. ${ }^{25}$

\section{ВЫВОДЫ}

В мире стабильно растет дефицит пресной воды. В связи с эти ведутся активные поиски экономически эффективных технологий опреснения вод морей и океанов. Практически эта задача решается с помощью выпарной техники в процессе дистилляции. Выпарные аппараты являются основными и при производстве жидких пищевых концентратов, спрос к которым на рынках постоянно растет. И в первой, и во второй задачах вода из раствора переводится в пар. Энергетический кризис вынуждает ориентироваться на альтернативные приемы разделения растворов. Поэтому растет интерес к криоконцентраторам и разработанным авторами вымораживающим разделительным установкам блочного типа. Главным отличием блочных вымораживателей является отсутствие системных потерь холода, что открывает новые возможности для сокращения затрат энергии. Авторы выдвинули гипотезу и доказали, что переход к условиям направленной кристаллизации при формировании блока льда позволит существенно расширить возможности вымораживателей блочного типа:

- за счет согласования конструктивных и режимных параметров обеспечить снижение суммарного термического сопротивления в процессе роста блока льда (эффект «термического парадокса»);
- за счет использования энергии блока льда, для переохлаждения холодильного агента перед его дросселированием, и применения частотного преобразователя снизить затраты электрической энергии на реализацию холодильного цикла.

Эти инновационные принципы реализованы в конструкции многофункциональной блочной вымораживающей установки. В результате комплексных испытаний установки установлены режимы, при которых затраты энергии минимальны. Оптимизация режимов работы позволила на 25\% снизить затраты электрической энергии в режиме рециклинга льда. Испытания проведены на молочной сыворотке, соках, экстрактах и воде Черного моря. Полученные концентраты и пресная вода отвечали всем технологическим стандартам. Резервы дальнейшего снижения расхода энергии за счет совершенствования конструкций и режимов работы блочных вымораживателей не исчерпаны.

Разработанная инновационная техника вымораживания имеет широкие межотраслевые перспективы.

\section{APPENDIX 1 (ПРИЛОЖЕНИЕ 1)}

${ }^{1,2}$ Table 1. Comparison of separation methods.

${ }^{3,4}$ Table 2. Comparison of freezing technologies on the ice fraction form-factor.

5,6Table 3. Cryoconcentration energy consumption $(\mathrm{kWh} / 1000 \mathrm{~kg}$ of ice).

${ }^{7,8}$ Table 4. Energy aspects of development of solution separation low-temperature technologies. 
${ }^{9}$ Fig. 1. Multifunctional block freezing plant with ice recycling. ( $a$ - principal scheme, $b-$ energy and product flows scheme).

${ }^{10}$ Fig. 2. Cooling cycle parameters dependence on the environment temperature.

${ }^{11}$ Fig. 3. Specific energy consumption dependence on the refrigerant boiling point for different solution concentrations.

12Fig. 4. Specific energy consumption dependence on the process time for different solution concentrations.

${ }^{13,14}$ Table 5. Experiment results of the Black Sea water demineralization.

${ }^{15}$ Fig. 5. Areas of block freezing technologies application.

16,17 Table 6. Main calculation results.

${ }^{18,19}$ Table 7. Calculated values of block freezing plant parameters.

${ }^{20,21}$ Table 8. Compressors technical characteristics.

${ }^{22}$ Fig. 6. Compressor energy consumption levels.

${ }^{23,24}$ Table 9. Economic indicators of schemes.

${ }^{25}$ Fig. 7. Frequency converter payback time.

\section{Литература (References)}

[1] UN-Water, Sustainable Development Goal 6: Synthesis Report on Water and Sanitation 2018. Available at: https://www.unwater.org/app/uploads/2018/05/U N-

Water_SDG6_Synthesis_Report_2018_Executive_S ummary_RUS.pdf (accessed 31.01.2022)

[2] Global Freshwater Challenges and Opportunities. A review of global freshwater management challenges, potential solutions, and opportunities for philanthropy, JULY 2014. Available at: https://www.ceaconsulting.com/wpcontent/uploads/Global-Freshwater-ExternalReport_CEA_July2014.pdf (accessed 31.01.2022)

[3] Kucera J. Desalination (Water from Water) Thermal Desalination Processes. 2019, pp. 51138. doi: 10.1002/9781119407874.ch2

[4] Mona M. Amin Abdel-Fatah and Ghada Ahmed Al Bazedi. Water Treatment and Desalination, Desalination $\neg$ Challenges and Opportunities, Mohammad Hossein Davood Abadi Farahani, Vahid Vatanpour and Amir Hooshang Taheri, IntechOpen, doi: 10.5772/intechopen.91471. Available

at: https://www.intechopen.com/chapters/71348 (accessed 31.01.2022)

[5] Global Water Desalination Market Size, Analysis, Growth Report, 2014-2025. Available at: https://www.hexaresearch.com/researchreport/water-desalination-market (accessed 31.01.2022)

[6] Orellana-Palma P., Guerra-Valle M., Zúñiga R.N. Centrifugal Filter-Assisted Block Freeze Crystallization Applied to Blueberry Juice. Processes, 2021, vol. 9, 421. doi: 10.3390/pr9030421
[7] Petzold G., Orellana P., Moreno J., Cerda E., Parra P. Vacuum-Assisted Block Freeze Concentration Applied to Wine. Innovative Food Science \& Emerging Technologies, 2016, vol. 36, pp. 330-335. doi: 10.1016/j.ifset.2016.07.019

[8] Orellana-Palma P., Zúñiga R.N., Takhar P.S., Gianelli M.P., Petzold G. Effects of Centrifugal Block Freeze Crystallization on Quality Properties in Pineapple Juice. Chemical Engineering \& Technology, 2020, vol. 43, no. 2, pp. 355-364. doi: 10.1002/ceat.201900387

[9] Meneses D.L., Ruiz Y., Hernandez E., Moreno F.L. Multi-Stage Block Freeze-Concentration of Green Tea (Camellia Sinensis) Extract. Journal of Food Engineering, 2021, vol. 293. doi: 10.1016/j.jfoodeng.2020.110381

[10] Barros E.L., Silva C.C., Canella M.H., Verruc, S., Prestes A.A., Vargas M.O., Maran B.M., Esmerino E.A., Silva R., Balthazar C.F., Calado V., Prudêncio E.S. Effect of Replacement of Milk by Block Freeze Concentrated Whey in Physicochemical and Rheological Properties of Ice Cream. Food Science and Technology International, 2021. doi: 10.1590/fst.12521

[11] Canella M.H., de Bona Muñoz I., da Silva Barros E.L., Silva C.C., de Sá Ploêncio L.A., Daguer H., Prudêncio E.S. Block Freeze Concentration as a Technique Aiming the Goat Milk Concentration: Fate of Physical, Chemical, and Rheological Properties. International Journal Of Engineering Sciences \& Research Technology, 2019, vol. 8, no. 5, pp. 88-104. doi: 10.5281/zenodo. 2836603

[12] Das D., Gupta A.K., Mishra P. Drying of Citrus Grandis (Pomelo) Fruit Juice Using Block Freeze Concentration and Spray Drying. Acta Alimentaria, 2020, vol. 49, no. 3, pp. 295-306. doi: 10.1556/066.2020.49.3.8

[13] Kharseh M. Utilize Freezing Water to Generate Energy. SN Appl. Sci, 2019, vol. 127, no. 1. doi: 10.1007/s42452-018-0139-z

[14] Mishra A. e.a. Aqua Life: A Compact Device Extracting Drinkable Water From Sea Water. Patent AU, no. 2021100286, 2021.

[15] Cordier C., Stavrakakis C., Morga B., Degrémont L., Voulgaris A., Bacchi A., Sauvade P., Coelho F., Moulin P. Removal of Pathogens by Ultrafiltration from Sea Water. Environment international, 2020, vol. 142 . doi: 10.1016/j.envint.2020.105809

[16] Tsoi C.C., Huang X., Leung P.H.M., Wang N., Yu W., Jia Y., Li Z., Zhang X. Photocatalytic Ozonation for Sea Water Decontamination. Journal of Water Process Engineering, 2020, vol. 37. doi: 10.1016/j.jwpe.2020.101501

[17] Cordier C., Stavrakakis C., Morga B., Degrémont L., Voulgaris A., Bacchi A., Sauvade P., Coelho F., Moulin P. Removal of Pathogens by Ultrafiltration from Sea Water. Environment International, 2020, vol. 142.

doi: 10.1016/j.envint.2020.105809 
[18] Siva Naik P., Naveen Kumar K., Praveen B., Kamalini Devi Dr. Desalination of Sea Water for Preparation of Drinking Water. EJASR, 2020, vol. 2, no. 8, pp. 10-18.

doi: 10.35338/EJASR.2020.2802

[19] Dolya S. Getting Fresh Water from Sea Water by Electrolysis. 2020. Available at: https://www.researchgate.net/publication/315573 285_Laser_Excitation_of_Sonic_Waves_in_the Candle_Flame (accessed 31.01.2022)

[20]Zambrano A., Ruiza Y., Hernández E., Raventós M., Moreno F.L. Freeze Desalination by the Integration of Falling Film and Block FreezeConcentration Techniques. Desalination, 2018, vol. 436, pp. 56-62.

doi: 10.1016/j.desal.2018.02.015

\section{Сведения об авторах.}

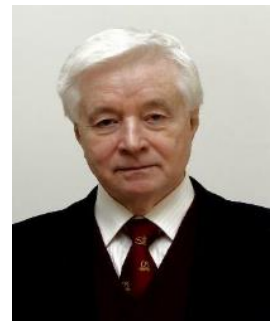

Бурдо Олег Григорьевич, д.т.н., профессор. Сфера научных интересов: процессы тепломассообмена, нанотехнологии в пищевой промышленности, энергоэффективность г. Одесса, Украина E-mail: poem.onaft@gmail.com
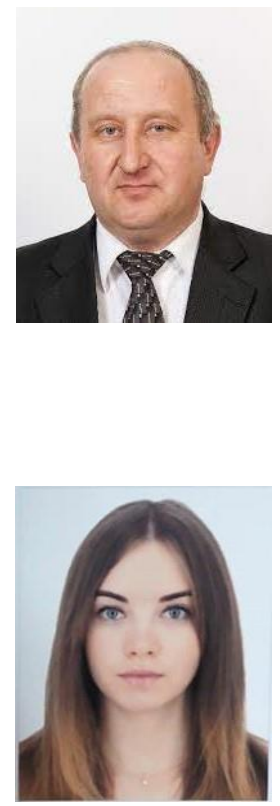

Мордынский Всеволод Петрович, к.т.н., доцент. Сфера научных интересов: технологии криоконцентрирования и опреснения

г. Одесса, Украина

E-mail:

poem.onaft@gmail.com

Фатеева Яна

Александровна, аспирант. Сфера научных интересов: технологии

криоконцентрирования и опреснения

г. Одесса, Украина

E-mail:
[21]Pap L. Kontsentrirovanie vymorazhivaniem. Moscow, Legkaya i Pishchevaya Promyshlennost', 1982.97 p.

[22] Trishyn F.A., Trach O.R., Orlovskaya Yu.V. Management of Energy Flows in Lowtemperature Separation Units. Problemele energeticii regionale, 2018, vol. 36, no. 1, pp. 72-86. doi: 10.5281/zenodo.1217274

[23] Petuhov B.S., Shykov V.K. Spravochnik po teploobmennikam: $V 2$ t. T. 1. Moscow, Energoatomizdat, 1987. 560p.

[24] https://www.danfoss.com/en/service-andsupport/downloads/dcs/coolselector-2/\#taboverview.

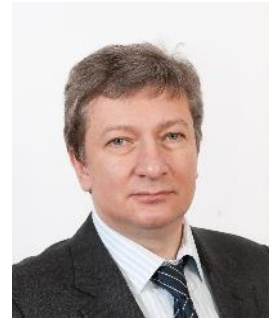

Терзиев

Сергей Георгиевич, д.т.н. Сфера научных интересов: процессы тепломассообмена, экоиндустрия в АПК, экстрагирование г. Одесса, Украина E-mail: poem.onaft@gmail.com

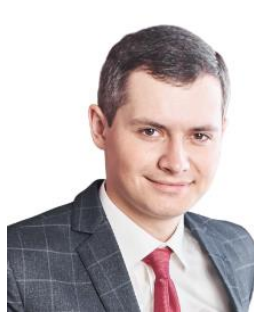

$\begin{array}{lr}\text { Сиротюк } & \text { Илья } \\ \text { Вадимович, } & \text { ассистент. } \\ \text { Сфера } & \text { научных } \\ \text { интересов: } \quad \text { процессы } \\ \text { тепломассообмена, } \\ \text { экстрагирование, } \\ \text { обезвоживание пищевых } \\ \text { продуктов, } \\ \text { энергоэффективность } \\ \text { г. Одесса, Украина } \\ \text { Е-таil: } \\ \text { ilyхin09@gmail.com }\end{array}$

yana.maselska@gmail.com 